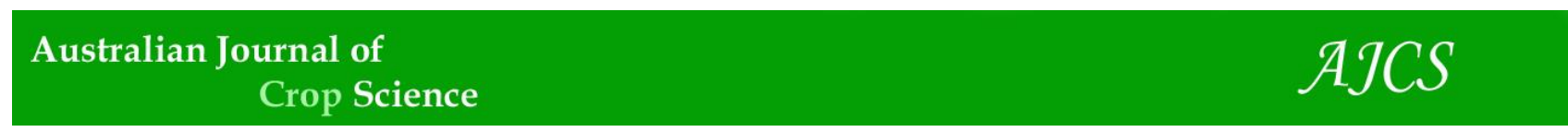

AJCS 12(01):151-156 (2018)

ISSN:1835-2707

doi: 10.21475/ajcs.18.12.01.pne819

\title{
Agronomic performance of jambu (Acmella oleracea) using organic fertilization
}

\section{Gilberta Carneiro Souto ${ }^{1}$, Leilson Costa Grangeiro ${ }^{2 *}$, Sergio Antônio Lopes de Gusmão ${ }^{3}$, Valdivia de Fátima Lima de Sousa ${ }^{2}$, Antônio Elson Cunha Cavalcante ${ }^{1}$, Francisco Diorge de França ${ }^{2}$}

\author{
${ }^{1}$ Instituto Federal do Pará (IFPA), BR 316, Km 61,Saudade II, CEP 68740-970, Castanhal, PA, Brazil \\ ${ }^{2}$ Instituto de Ciências Agrárias, Universidade Federal Rural do Semi-Árido (UFERSA), Av. Francisco Mota, 572, Costa \\ e Silva, CEP 59625-900, Mossoró, RN, Brazil \\ ${ }^{3}$ Instituto de Ciências Agrárias, Universidade Federal Rural da Amazônia (UFRA), Av. Perimetral, 2501, Terra Firme, \\ CEP 66077-830, Belém, PA, Brazil
}

*Corresponding author: leilson@ufersa.edu.br

\begin{abstract}
Jambu is a plant species from the northern region of Brazil, where it is widely used in food as a seasoning in typical regional dishes, and in folk medicine. The objective of this work was to evaluate the agronomic performance of jambu under organic fertilization. The experiments were conducted under field conditions for the periods January to February, 2015 (Period 1) and May to June, 2015 (Period 2), in soil classified as dystrophic yellow latosol of medium texture. The experimental design was randomized complete block, using a $2 \times 5$ factorial scheme, with four replicates. The treatments consisted of two jambu accesses (Purple Flower and Yellow Flower), and six doses of organic fertilizer $\left(0,2,4,6,8\right.$, and $10 \mathrm{~kg} \mathrm{~m}^{-2}$ ) produced from a mixture of organic compost (mixture of leaves of Syzygium malaccense, Inga edulis, Mangifera indica, and Zoysia japonica) and vermicompost in a volume ratio of 1:1. The following characteristics were evaluated: plant height, fresh mass, and productivity. The best jambu agronomic performance (in terms of yield) was obtained with the application of $10 \mathrm{~kg} \mathrm{~m}^{-2}$ of organic fertilizer, with higher productivity in the cultivation performed between May and June, 2015. The Yellow Flower access was more productive than the Purple Flower access.
\end{abstract}

Keywords: Acmella oleracea L.; organic fertilizer; fresh mass of plant; vermicompost; plant nutrition.

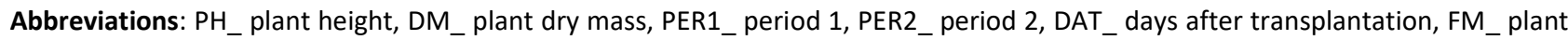
fresh mass, PROD_productivity.

Introduction

The jambu plant (Acmella oleracea L.) is a leaf vegetable, widely consumed in the northern Brazilian region as a seasoning and medicinal herb. Its flavor is quite peculiar, its flowers producing a sensation of tingling and torpidity of the mouth mucosa, due to the presence of spilanthol (Borges et al., 2012; Borges et al., 2014). In the state of Pará, jambu is cultivated by periurban producers in small areas, together with other seasoning and leaf vegetables, such as coriander, lettuce, and chives, especially to sustain the consumption of the city of Belém and the main urban centers of the northeastern mesoregion of the state (Homma et al., 2011). The most cultivated access has light green leaves with yellow flowers, but there is also the purple jambu, the leaves of which have a more intense shade of green, and with purple branches, and flowers with a purplish halo (Martins et al., 2012; Gusmão and Gusmão, 2013). The use of organic fertilizers in the production of vegetables is important, not only because they provide nutrients to the plants, but also due to the improvements they give to the physical and biological condition of the soil, thus contributing to a better uptake of the applied nutrients (Webb et al., 2010).
In jambu crops, research on fertilization is limited, mainly relating to the influence of organic fertilization on production. Oliveira and Ineco (2015), studying organic fertilization doses in jambu, obtained a maximum yield of $323.7 \mathrm{~m}^{-2}$ of flower buds and $53.92 \mathrm{~g} \mathrm{~m}^{-2}$ of dry mass, with a $4.0 \mathrm{~kg} \mathrm{~m}^{-2}$ dose of organic fertilizer. Borges et al. (2013a) evaluated doses of cattle manure (2 to $\left.10 \mathrm{~kg} \mathrm{~m}^{-2}\right)$ and urea ( 0 to $150 \mathrm{~m}^{-2}$ ) in the Jamburana cultivar, and obtained higher productivity using urea as a fertilizer, as opposed to the manure; a dose of $90 \mathrm{~g} \mathrm{~m}^{-2}$ of urea provided higher productivity $\left(4.40 \mathrm{~kg} \mathrm{~m}^{-2}\right)$, than the $2.78 \mathrm{~kg} \mathrm{~m}^{-2}$ provided by a $4 \mathrm{~kg} \mathrm{~m}^{-2}$ dose of cattle manure. Organic fertilization of jambu also influences the content of plant phytochemical compounds. Borges et al. (2012) observed increases of $31.6 \%$ in the content of spilantol and $16.8 \%$ of flavonoids in inflorescence, compared to conventional fertilization. Organic fertilizer induced higher levels of total phenolics, carotenoids, spermidine, and spermine in leaves and flowers of jambu than under conventional cultivation (Borges et al., 2016).There are various recommendations of organic fertilization for vegetable production; however, to define more precise doses, information, such as soil analysis, 
history of the place to be fertilized, and type of organic fertilization, are required. In this context, the objective of this work was to evaluate the agronomic performance of jambu as a function of organic fertilization.

\section{Results and discussion}

Significant effects were observed for periods, accesses, and organic fertilizer doses, for all characteristics. The only exception was verified for accesses in plant height (PH). For almost all characteristics, the period interacted with both the accesses and the doses. Again, an exception was observed for $\mathrm{PH}$, in period and access interaction. The access and dose interactions were significant for PH and DM. A triple interaction among accesses, doses, and periods was significant only for DM.

\section{Plant height and fresh mass}

Analyzing planting period/organic fertilizer dose interaction, it was verified that PH increased linearly in both periods, with estimated maximums of 32.29 and $42.72 \mathrm{~cm}$ in PER1 and PER2, respectively, obtained with the application of 10 $\mathrm{kg} \mathrm{m}{ }^{-2}$ of organic fertilizer (Fig. 1). In relation to the treatment with no organic fertilizer application, increases were $69.4 \%$ and $91.8 \%$ in PER1 and PER2, respectively. The greatest nutrient availability in the soil helped plant growth in terms of height. Plants were taller in the cultivation from May to June (PER2), regardless of the organic fertilizer dose used (Table 1), and with the application of $10 \mathrm{~kg} \mathrm{~m}^{-2}$, the average estimated PH in PER2 was $32.3 \%$ higher than in PER1. Probably, higher rainfall volume occurring between January and February (summer) affected plant growth. Gusmão and Gusmão (2013) determined that jambu develops well at high temperatures, with air relative humidity around 90\%; however, heavy rainfall over prolonged periods helps the occurrence of diseases, physically damages plants, and causes wash-off of nutrients from the soil, as well as reducing the availability of sunlight, thus resulting in lowered productivity. As for the interaction between accesses and organic fertilizer doses, the accesses' response to the application of organic fertilizer was linear and quadratic, with estimated maximums of 37.55 and 35.42 $\mathrm{cm}$, respectively, for the purple and yellow flowers, obtained with the application of $10 \mathrm{~kg} \mathrm{~m}^{-2}$ (Fig. 2). These are higher than those determined by Borges et al. (2013a), who obtained a maximum jambu $\mathrm{PH}$ of $25.62 \mathrm{~cm}$, with the application of $8 \mathrm{~kg} \mathrm{~m}^{-2}$ of cattle manure under field conditions, and 21.50 and $27.24 \mathrm{~cm}$, respectively, for the Nazaré and Jamburana cultivars, with the application of $8 \mathrm{~kg}$ $\mathrm{m}^{-2}$ of cattle manure, plus $3 \mathrm{~kg} \mathrm{~m}^{-2}$ of castor bean cake (in covering), in a protected environment, in the southern region of Brazil (Borges et al., 2014). In the interaction between doses and accesses, there was a significant difference only in the dose of organic fertilizer of $6 \mathrm{~kg} \mathrm{~m}^{-2}$, with the yellow flower access being superior. This allowed the observation that, starting from $6 \mathrm{~kg} \mathrm{~m}^{-2}$, the yellow flower tended to stabilize, whereas the purple flower kept responding to the fertilization (Fig. 2).

The FM of jambu increased as the application of organic fertilizer doses also increased in the two planting periods, reaching the highest values with $10 \mathrm{~kg} \mathrm{~m}^{-2}$ (Fig. 3); however, between the planting periods, the difference was statistically significant, starting from the $6 \mathrm{~kg} \mathrm{~m}^{-2}$ dose, when there was PER2 superiority (Table 1 ). The estimated FM maximums were, respectively, 125.6 and $160.59 \mathrm{~g}$ in PER1 and PER2 (Fig. 3). As for the treatment with no organic fertilizer application, increases were $187.8 \%$ and $517.2 \%$ in PER1 and PER2, respectively. Various authors have reported that the application of organic fertilizer provides significant increases in the FM of vegetables crops, such as lettuce (Almeida et al., 2008; Santana et al., 2012), rocket (Solino et al., 2010), and carrot (Pimentel et al., 2009). Borges et al. (2013a) did not confirm any significant increases in the FM of jambu using organic fertilization doses. The yellow flower access stood out in relation to the purple in PER1, and there was no significant difference between them in PER2. Between the periods, there was significant difference only in the purple flower, with the highest FM in PER 2 (Table 2), indicationg that this access is likely more vulnerable to heavy rainfall, as verified in PER1. Borges et al. (2014) verified significant differences between the jambu plant cultivars Jamburana and Nazaré in leaf FM with the use of organic fertilization, with Jamburana having superiority over Nazaré, with averages of 169.62 and $86.67 \mathrm{~g}$, respectively.

\section{Productivity and dry mass}

Productivity, according to the organic fertilizer doses, presented a linear adjustment in both planting periods. The estimated maximums were 3.14 and $4.02 \mathrm{~kg} \mathrm{~m}^{-2}$ in PER1 and PER2, respectively (Fig. 3). Productivity has an intimate relationship with the $\mathrm{FM}$ of plants, in that they present similar responses; however, between the planting periods, the difference was statistically significant starting from the 6 $\mathrm{kg} \mathrm{m}^{-2}$ dose, when there was PER2 superiority (Table 1 ).

Borges et al. (2013b), through application of cattle manure and urea, with equivalent $\mathrm{N}$ content, to jambu plants, did not observe any significant effect on productivity, obtaining a maximum productivity of $2.78 \mathrm{~kg} \mathrm{~m}^{-2}$ with the application of $4 \mathrm{~kg} \mathrm{~m}^{-2}$ of cattle manure; however, the application of 90 $\mathrm{g} \mathrm{m}^{-2}$ of urea provided $4.40 \mathrm{~kg} \mathrm{~m}^{-2}$.

In general, responses to organic fertilizer doses are variable, thus not allowing the establishment of a standard dose. Nutrients are quite variable in each compost, depending on the origin, and each situation observed in the field differs from another for different reasons, such as the quantity of organic matter in the soil, the practice or not of previous organic fertilization, the type of soil used, the previous culture, and the used cultivars (Melo et al., 2008).

The $10 \mathrm{~kg} \mathrm{~m}^{-2}$ dose of organic fertilizer, responsible for the highest productivity in the two experiments, is much higher than that recommended by Botelho et al. (2007) for the cultivation of leaf vegetables (lettuce, jambu) in the state of Pará, Brazil (more like 3.0 to $4.0 \mathrm{~kg} \mathrm{~m}^{-2}$, or 30 to $40 \mathrm{t} \mathrm{ha}^{-1}$ ); however, previous studies have complemented their organic doses with inorganic fertilization, using 100 to $300 \mathrm{~kg} \mathrm{ha}^{-1}$ of $\mathrm{P}_{2} \mathrm{O}_{5}$ in planting, and in covering $90 \mathrm{~kg} \mathrm{ha}^{-1}$ with $\mathrm{N}$ and 60 to $120 \mathrm{~kg} \mathrm{ha}^{-1}$ with $\mathrm{K}_{2} \mathrm{O}$, parceled at 10,20 , and 30 days after transplanting.

Similarly to FM, the yellow flower access stood out in productivity terms, in relation to the purple flower, in PER1 and there was no significant difference between them in PER2. Between the periods, there was significant difference 
Table 1. Plant height (PH), fresh mass (FM), and productivity (PROD) of jambu plants, according to planting season and organic fertilizer doses.

\begin{tabular}{lcccccc}
\hline $\begin{array}{l}\text { Organic fertilizer } \\
\left(\mathrm{kg} \mathrm{m}^{-2}\right)\end{array}$ & \multicolumn{2}{c}{$\mathrm{PH}(\mathrm{cm})$} & \multicolumn{2}{c}{ FM $(\mathrm{g})$} & \multicolumn{2}{c}{ PROD $\left(\mathrm{kg} \mathrm{m}^{-2}\right)$} \\
\hline 0 & $17.32 \mathrm{~b}$ & $22.27 \mathrm{a}$ & $40.42 \mathrm{a}$ & $37.47 \mathrm{a}$ & $1.01 \mathrm{a}$ & $0.93 \mathrm{a}$ \\
2 & $21.97 \mathrm{~b}$ & $25.42 \mathrm{a}$ & $56.50 \mathrm{a}$ & $38.83 \mathrm{a}$ & $1.41 \mathrm{a}$ & $0.97 \mathrm{a}$ \\
4 & $25.15 \mathrm{~b}$ & $31.06 \mathrm{a}$ & $75.31 \mathrm{a}$ & $62.64 \mathrm{a}$ & $1.88 \mathrm{a}$ & $1.57 \mathrm{a}$ \\
6 & $29.36 \mathrm{~b}$ & $36.67 \mathrm{a}$ & $108.38 \mathrm{~b}$ & $131.86 \mathrm{a}$ & $2.71 \mathrm{~b}$ & $3.30 \mathrm{a}$ \\
8 & $30.08 \mathrm{~b}$ & $38.24 \mathrm{a}$ & $111.92 \mathrm{~b}$ & $134.27 \mathrm{a}$ & $2.80 \mathrm{~b}$ & $3.36 \mathrm{a}$ \\
10 & $30.14 \mathrm{~b}$ & $41.83 \mathrm{a}$ & $115.33 \mathrm{~b}$ & $154.76 \mathrm{a}$ & $2.90 \mathrm{~b}$ & $3.87 \mathrm{a}$ \\
\hline
\end{tabular}

Means followed by the same letter in the line did not differ significantly at $5 \%$ of probability by Tukey's test.

PER 1: January to February, 2015; PER2: May to June, 2015.

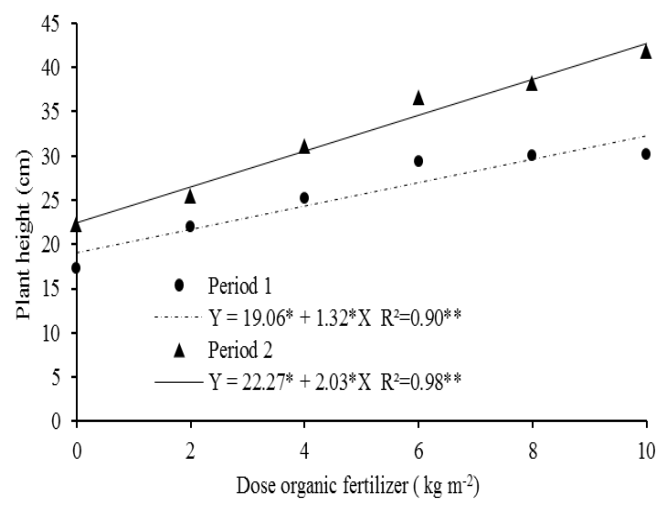

Fig 1. Height of jambu plants in January-February 2015 - PER1 (•) and May-June 2015 - PER2 (4) crops, according to organic fertilizer doses.

Table 2. Fresh mass (FM) and productivity (PROD) of jambu plant accesses, according to planting period.

\begin{tabular}{lcccc}
\hline \multirow{2}{*}{ Period } & \multicolumn{3}{c}{ FM $(\mathrm{g})$} & \multicolumn{2}{c}{ PROD $\left(\mathrm{kg} \mathrm{m}^{-2}\right)$} \\
\cline { 2 - 5 } & Purple flower & Yellow flower & Purple flower & Yellow flower \\
\hline 1 & $71.11 \mathrm{Bb}$ & $98.18 \mathrm{Aa}$ & $1.78 \mathrm{Bb}$ & $2.46 \mathrm{Aa}$ \\
2 & $91.48 \mathrm{Aa}$ & $95.13 \mathrm{Aa}$ & $2.29 \mathrm{Aa}$ & $2.38 \mathrm{Aa}$ \\
\hline
\end{tabular}

Means followed by the same lowercase letter in the line and uppercase in the column do not differ significantly at $5 \%$ of probability by Tukey's test.

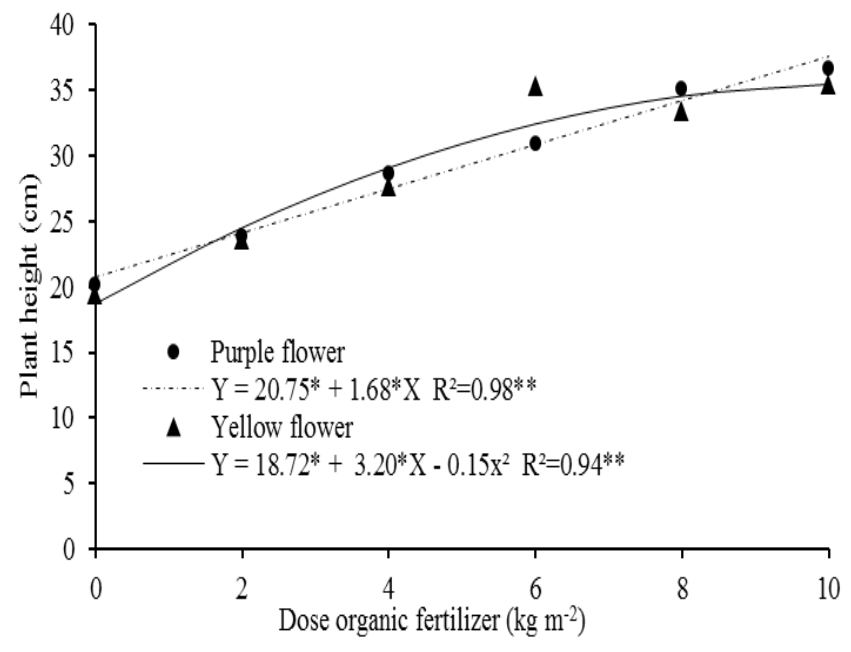

Fig 2. Height of jambu plants, Purple flower $(\bullet)$ and Yellow flower $(\boldsymbol{\Delta})$ accesses, according to organic fertilizer doses. 

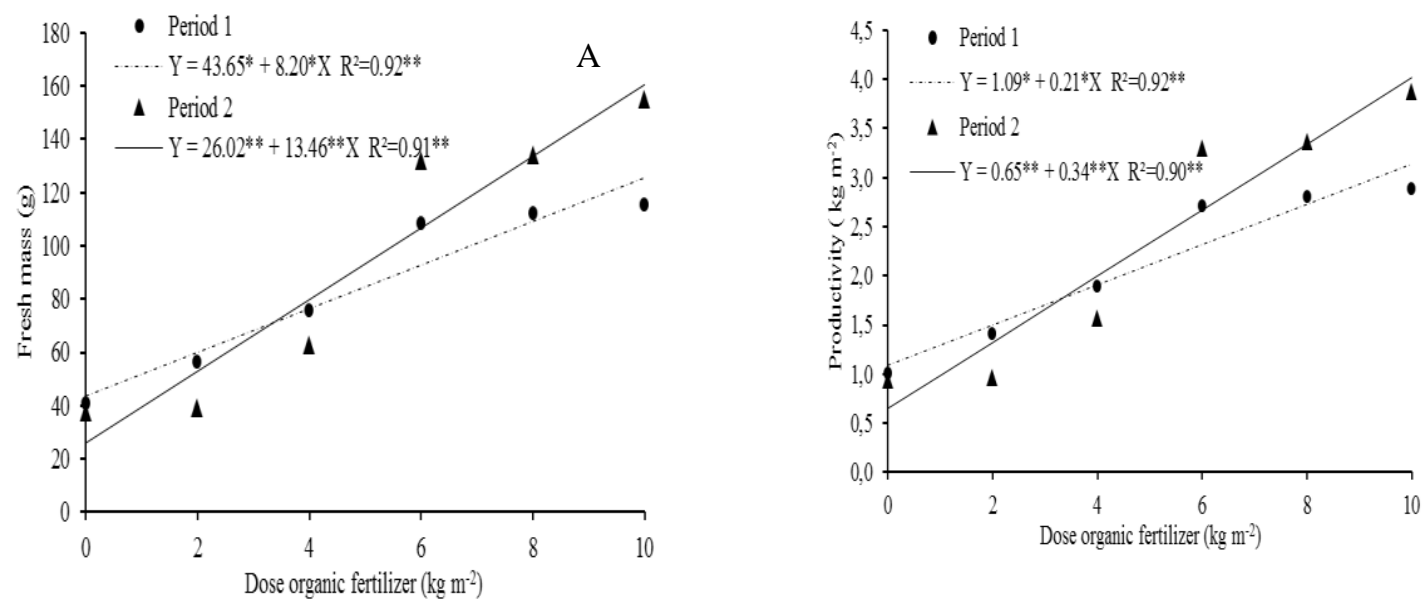

Fig 3. Fresh mass (A) and productivity (B) of jambu plants in January-February 2015 - PER1 (•) and May-June 2015 - PER2 ( $\mathbf{\Delta}$ ) crops, according to organic fertilizer doses.
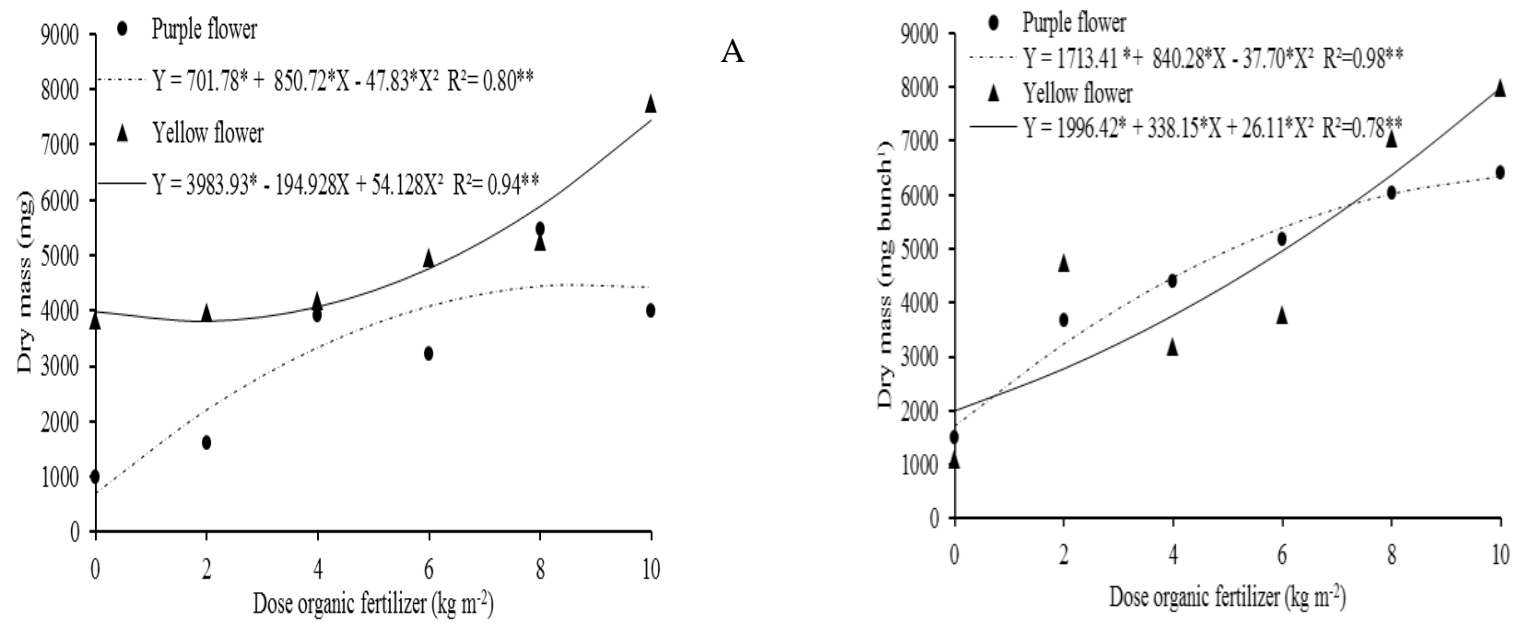

Fig 4. Dry mass of jambu plants, purple flower $(\bullet)$ and yellow flower $(\boldsymbol{\Delta})$ accesses, according to organic fertilizer doses, JanuaryFebruary (A) and May-June (B) 2015 crops.

only in the purple flowe, with higher productivity in PER2 (Table 2). Productivity, in this work 3.14 and $4.02 \mathrm{~kg} \mathrm{~m}^{-2}$, respectively, for PER1 and PER2, was higher than those obtained by Borges et al. (2013b: averages of $3.37 \mathrm{~kg} \mathrm{~m}^{-2}$ with mineral fertilization, and $2.40 \mathrm{~kg} \mathrm{~m}^{-2}$ with organic fertilization), and also than the average productivity obtained by Pará producers, which is from 6 to 10 bunches $\mathrm{m}^{-2}$ (1.8 to $3.0 \mathrm{~kg} \mathrm{~m}^{-2}$ ), according to Rodrigues et al. (2014).

The averages of DM (bunch with five plants), according to dose of organic fertilizer, were adjusted to the model of quadratic regression in both planting periods. In PER1, the estimated maximums were 4484.03 and $7446.96 \mathrm{mg}$ for the purple and yellow flower accesses, respectively, obtained with the application of 9.0 and $10 \mathrm{~kg} \mathrm{~m}^{-2}$ of organic fertilizer. In PER2, these values were 6346.21 and $7988.86 \mathrm{mg}$, obtained with the application of $10 \mathrm{~kg} \mathrm{~m}^{-2}$ (Fig. 4). Considering the doses that provided the highest values, the yellow flower access presented DM production that was 67.5 and $25.9 \%$ higher than for the purple in PER1 and PER2, respectively. In a work conducted by Oliveira and Inneco (2015), the DM of jambu inflorescences, according to organic fertilizer doses, presented a maximum with the application of $4.0 \mathrm{~kg} \mathrm{~m}^{-2}$. This differs from the results obtained by Borges et al. (2013b), who did not verify significant increases in jambu DM, according to organic fertilization doses.

\section{Materials and Methods}

\section{Site location and characterization}

The experiments were conducted, under field conditions, at the Instituto Federal do Pará, located in the municipality of Castanhal, Pará state, Brazil ( $\left.1^{\circ} 17^{\prime} 46^{\prime \prime} \mathrm{S}, 47^{\circ} 55^{\prime} 28^{\prime \prime} \mathrm{W}\right)$, in the periods from January to February, 2015 (Period 1) and May to June, 2015 (Period 2). The soil of the experimental area was classified as dystrophic yellow latosol, with medium texture (EMBRAPA, 2006), with the following characteristics for the 0 to $20 \mathrm{~cm}$ layer: in Period $1-\mathrm{pH} \mathrm{6.0;} \mathrm{organic} \mathrm{matter}$ 
$=23.7 \mathrm{~g} \mathrm{~kg}^{-1} ; \mathrm{P}_{\text {(Mehlich1) }}=191.0 \mathrm{mg} \mathrm{dm}^{-3} ; \mathrm{K}^{+}=43.6 \mathrm{mg} \mathrm{dm}^{-3}$; $\mathrm{Na}^{+}=7.2 \mathrm{cmol}_{\mathrm{c}} \mathrm{dm}^{-3} ; \mathrm{Ca}^{2+}=4.3 \mathrm{cmol}_{\mathrm{c}} \mathrm{dm}^{-3} ; \mathrm{Mg}^{2+}=0.9 \mathrm{cmol}_{\mathrm{C}}$ $\mathrm{dm}^{-3} ; \mathrm{Al}^{3+}=0.1 \mathrm{cmol}_{\mathrm{c}} \mathrm{dm}^{-3} ; \mathrm{H}^{+}+\mathrm{Al}^{3+}=2.2 ;$ and Period $2-\mathrm{pH}$ 6.5 ; organic matter $=21.5 \mathrm{~g} \mathrm{~kg}^{-1} ; \mathrm{P}_{(\text {Mehlich1 })}=277.3 \mathrm{mg} \mathrm{dm}^{-3}$; $\mathrm{K}^{+}=62.6 \mathrm{mg} \mathrm{dm}{ }^{-3} ; \mathrm{Na}^{+}=8.2 \mathrm{cmol}_{\mathrm{C}} \mathrm{dm}^{-3} ; \mathrm{Ca}^{2+}=3.3 \mathrm{cmol}_{\mathrm{c}} \mathrm{dm}^{-}$ ${ }^{3} ; \mathrm{Mg}^{2+}=1.2 \mathrm{cmol}_{\mathrm{c}} \mathrm{dm}^{-3} ; \mathrm{Al}^{3+}=0.1 \mathrm{cmol}_{\mathrm{c}} \mathrm{dm}^{-3} ; \mathrm{H}^{+}+\mathrm{Al}^{3+}=1.3$ $\mathrm{cmol}_{\mathrm{c}} \mathrm{dm}^{-3}$.

The climate of the region, according to Köppen, is Af type, tropical rainforest, with an annual average temperature of $26.5{ }^{\circ} \mathrm{C}$, and annual medium rainfall of $2432 \mathrm{~mm}$. During January and February (Period 1), rainfall was $306.8 \mathrm{~mm}$, and the averages of the maximum, minimum, and average temperatures were $34.1,22.3$, and $26.4^{\circ} \mathrm{C}$. During May and June (Period 2), rainfall was $214.4 \mathrm{~mm}$, and the averages of the maximum, minimum, and average temperatures were $33.4,22.3$ and $26.6^{\circ} \mathrm{C}$, respectively.

\section{Treatments and experimental design}

The experimental design was randomized complete block, using a $2 \times 5$ factorial scheme, with four replicates. The treatments resulted from the combination of two jambu accesses (purple flower and yellow flower) and six doses of organic fertilizer $\left(02,4,6,8\right.$, and $\left.10 \mathrm{~kg} \mathrm{~m}^{-2}\right)$. The experimental unit consisted of a $3 \times 1 \mathrm{~m}$ bed, with five rows of plants, spaced $0.2 \times 0.2 \mathrm{~m}$ apart, making a total area of 3.0 $\mathrm{m}^{2}$, being considered as a useful area, the three central rows.

The doses were based on the recommendation of Botelho et al. (2007) for leafy vegetables in the State of Pará (3.0 to $4.0 \mathrm{~kg} \mathrm{~m}^{-2}$, or 30 to $40 \mathrm{t} \mathrm{ha}^{-1}$ of organic compost or manure).

\section{Plant materials}

The accesses of jambu used are known in the region as yellow flower and purple flower. The seeds were got from producers in the municipality of Castanhal, State of Pará.

\section{Organic fertilizer}

The organic fertilizer consisted of a mixture of organic compost and vermicompost. The organic compost was prepared by making a stack of approximately $1 \mathrm{~m}$ tall, with dry leaves (a mixture of Syzygium malaccense, Inga edulis, Mangifera indica and Zoysia japonica) and bovine manure in a volume ratio of 3:1. Stack tumbling was performed weekly during the curing process, which is closed after approximately 60 days. The vermicompost used came from the production of California red earthworms (Eisenia foetida), based on bovine manure.

The organic compost and vermicompost was mixed in a volume ratio of 1:1. The chemical composition of the organic fertilizer, after mixing, was as follows: $\mathrm{pH}=6.2 ; \mathrm{C} / \mathrm{N}$ ratio $=$ $13 / 1$; humidity $=40 \%$; organic matter $=18.5 \%$; in $\mathrm{g} \mathrm{kg}^{-1}: \mathrm{N}=$ 8.0; $\mathrm{P}=3.4 ; \mathrm{K}=2.1 ; \mathrm{Ca}=7.7 ; \mathrm{Mg}=2.7 ; \mathrm{S}=2.3 ; \mathrm{C}=102.7$; in $\mathrm{mg} \mathrm{kg}^{-1}: \mathrm{Fe}=3115 ; \mathrm{Cu}=22 ; \mathrm{Mn}=181 ; \mathrm{Na}=534 ; \mathrm{Zn}=98$, and $B=7$.

\section{Field establishment}

Sowing was performed in polystyrene trays of 128 cells, containing vermicompost as substrate, ten seeds per cell. After germination of the seeds, thinning was carry out, leaving five plants per cell. Transplanting to the field was performed 30 days after sowing, using a spacing of $0.2 \times 0.2$ $\mathrm{m}$.

Soil preparation consisted of harrowing, followed by lifting of the beds. The sowing fertilization was carried out with half the dose of the organic fertilizer (according to the treatment), distributed on the surface of the bed, with subsequent incorporation into the $5 \mathrm{~cm}$ layer. The other half was applied under cover, parceled at 10 and 20 days after transplantation (DAT) of the jambu, in equal parts. In the absence of rainfall, irrigation was applied daily, using an irrigation microsprinkler system. Weed control took place whenever necessary.

\section{Harvesting and parameters evaluated}

Harvesting was performed when $30 \%$ of the plants had flower buds, at 42 DAT. The jambu plants were cut at the level of the soil surface. The following characteristics were evaluated:

Plant height $(\mathrm{cm})$ - determined as the distance between the tip of the highest leaf and the soil, measured for 10 plants in the useful area of the plot.

Fresh mass (g) and dry mass ( $\mathrm{mg}$ ) - determined by weighing a five-plant bunch. For the dry mass, the plants were dried at $65^{\circ} \mathrm{C}$ until constant mass was reached.

Productivity $\left(\mathrm{kg} \mathrm{m}^{-2}\right)$ - determined from the fresh mass of the plants, harvested from the useful area of the plot.

\section{Statistical analysis}

Analyses of variance of the data from the evaluated characters were performed separately for each experiment and, afterwards, a joint analysis of the experiments was performed with the help of the SISVAR software (Ferreira, 2011). For the organic fertilizer dose, regression analysis was performed, whereas for the accesses and cultivation period, Tukey's test at $5 \%$ probability was used.

\section{Conclusions}

The best jambu plant agronomic performance was obtained with the application of $10 \mathrm{~kg} \mathrm{~m}^{-2}$ of organic fertilizer, with higher productivity in the cultivation performed between May and June, 2015. The yellow flower access was more productive than the purple flower access. Further studies are needed to investigate how to make organic fertilization more efficient for jambu crops. Such studies should examine periods of application and nutrient availability from organic fertilizer, as well as the long-term effects of the incorporation of organic fertilizer in the soil.

\section{References}

Almeida MMTB, Lixa AT, Silva EE, Azevedo PHS, De-Polli H, Ribeiro RD (2008) Fertilizantes de leguminosas como fontes alternativas de nitrogênio para produção orgânica de alface. Pesqui Agropecu Bras. 43(6): 675-682.

Borges LS, Vieira MAR, Marques MOM, Vianello F, Lima GPP (2012) Influence of organic and mineral soil fertilization on essential oil of Spilanthes oleracea cv. Jamburana. Am J Plant Physiol. 7(3): 135-142. 
Borges LS, Goto R, Guerrero AC (2013a) Exportação de nutrientes em plantas de jambu, sob diferentes adubações. Semin-Cien Agrar. 34(1): 107-116.

Borges LS, Guerrero AC, Goto R, Lima GPP (2013b) Produtividade e acúmulo de nutrientes em plantas de jambu, sob adubação orgânica e mineral. Semin-Cien Agrar. 34(1): 83-94.

Borges LS, Goto R, Giuseppina PPL (2014) Índices morfofisiológicos e produtividade de cultivares de jambu influenciadas pela adubação orgânica e mineral. Biosci J. 30(6): 1768-1778.

Borges LS, Vieira MCMS, Vianello F, Goto R, Lima GPP (2016) Antioxidant compounds of organically and conventionally fertilized jambu (Acmella oleracea). Biol Agric Hortic 32(3): 149-158.

Botelho SM, Cheng S, Viegas IJM (2007) Alface e outras Folhosas (Jambu, Coentro, Salsa, Cebolinha, Couve, Rúcula, Chicorinha). In: Cravo MS, Viegas IJM, Brasil EC (eds) Recomendações de adubação e calagem para o Estado do Pará, Belém: Embrapa Amazônia Oriental, pp.189-190.

EMBRAPA (Empresa brasileira de pesquisa agropecuária) (2006) Sistema brasileiro de classificação de solos, Rio de Janeiro: Embrapa informações tecnológicas, 306p .

Ferreira DF (2011) SISVAR: A Computer statistical analysis system. Cienc Agrotec. 35(6): 1039-1042.

Gusmão MTA, Gusmão SAL (2013) Jambu da Amazônia Acmella oleracea[(L) RK Jansen]: Caracteristicas gerais, cultivo convenciona, orgânico e hidropônico, Belém: Editora UFRA, 135p.

Homma AKO, Sanches RS, Menezes AJEA, Gusmão SA (2011) Etnocultivo do jambu para Abastecimento da cidade de Belém. Amazonia-Cienc Desenv. 6(12): 125-141.

Martins CPS, Melo MTP, Honório ICG, D'Ávila VA, Carvalho Júnior WGO (2012) Caracterização morfológica e agronômica de acessos de jambu (Spilanthes oleracea L.) nas condições do Norte de Minas Gerais. Rev Bras Plantas Med. 14(2): 410-413.

Melo LCA, Silva CA, Dias BO (2008) Caracterização da matriz orgânica de resíduos de origens diversificadas. Rev Bras Cienc Solo 32(1): 101-110.

Oliveira MAS, Innecco R (2015) Produção de biomassa de inflorescências em função de espaçamentos e adubação orgânica com jumbu (Acmella Oleracea - Asteraceae). Essentia 16: 1-11.

Pimentel MS, De-Polli H, Lana AMQ (2009) Atributos químicos do solo utilizando composto orgânico em consórcio de alface-cenoura. Pesqui Agropecu Bras. 39(3): 225-232.

Rodrigues DS, Camargo MS, Nomura ES, Garcia VA, Correa JN, Vidal TCM (2014) Influência da adubação com nitrogênio e fósforo na produção de jambu, Acmella oleracea (L) R. K . Jansen. Rev. Rev Bras Plantas Med. 16(1): 71-76.

Santana CTC, Santi A, Dallacort R, Santos ML, Menezes CB (2012) Desempenho de cultivares de alface americana em resposta a diferentes doses de torta de filtro. Rev Cienc Agron. 43(1): 22-29.

Solino AJS, Ferreira RO, Ferreira RLF, Araújo Neto SE, Negreiro JRS (2010) Cultivo orgânico de rúcula em plantio direto sob diferentes tipos de coberturas e doses de composto. Rev Caatinga 23(2): 18-24.

Webb J, Pain B, Bittman S, Morgan J (2010) The impacts of manure application methods on emissions of ammonia, nitrous oxide and on crop response - A review. Agr Ecosyst Environ. 137: 39-46. 